\title{
Management of Coffee White Stem Borer Xylotrechus quadripes (Chevrolat, 1863) (Coleoptera: Cerambycidae) in the Lower Pulney Hills, India
}

\author{
K.R. Manikandan ${ }^{1}$, M. Muthuswami ${ }^{2 *}$, N. Chitra ${ }^{2}$ and M. Ananthan ${ }^{3}$ \\ ${ }^{1}$ Department of Agricultural Entomology, Thadiyankudisai 624212, Dindigul, Tamilnadu, India \\ ${ }^{2}$ Department of Agricultural Entomology, Tamil Nadu Agricultural University, \\ Coimbatore, 641 003, Tamil Nadu, India \\ ${ }^{3}$ Directorate of Open and Distance Learning, Tamil Nadu Agricultural University, \\ Coimbatore, 641 003, Tamil Nadu, India \\ *Corresponding author
}

\section{A B S T R A C T}

\section{Keywords}

Coffee, White stem borer, Bio-efficacy, Bio-agents, Synthetic insecticides, Coffee yield

Article Info

Accepted:

15 May 2019

Available Online:

10 June 2019
The bio-efficacy of bio-agents viz., Beauveria bassiana 2\% A.S. @ 10ml/lit, Bacillus subtilis@10/lit and azadirachtin 1\% EC @ 1ml/lit and chemical insecticide viz., chlorpyriphos 20 EC @ 3ml/lit, chlorantraniliprole 20 SC @ 0.5ml/lit and fipronil 40\% + imidacloprid 40\% WG @ 0.5g/lit were assessed against coffee white stem borer Xylotrechus quadripes (Chevrolat, 1863) (Cerambycidae: Coleoptera) in lower Pulney hills, Tamil Nadu. Coinciding with the adult emergence, three sprays were given: I spray (first week of April, 2018), II spray (first week of October, 2018) and III spray (last week of October, 2018) in two field trials, compared with untreated control. In both field trials the maximum control was observed in chlorpyriphos $20 \mathrm{EC}+$ azadirachtin 1\% EC @ 3ml $+1 \mathrm{ml}(45.56 \%$ and $36.67 \%)$ followed by chlorpyriphos $20 \mathrm{EC} @ 3 \mathrm{ml} / \mathrm{lit}$ (45.56\% and $37.72 \%)$, Beauveria bassiana 2\% A.S. @ 10ml/lit (48.89\% and $43.33 \%)$ and chlorantraniliprole 20 SC @ 0.5ml/lit (51.67\% and 46.11\%) as against control $(84.44 \%$ and $80.56 \%$ ).

\section{Introduction}

Coffee (Coffea arabica) the most important perennial beverage plant is believed to have been introduced into India in the Chikmagalur hills in $1600 \mathrm{AD}$ by a Muslim pilgrim, Bababudan from Yemen (Central Coffee Research Institute (CCRI, 2003). In the late 1820 's coffee plantations were established in South India by the British. At present in India, coffee (arabica and robusta) cultivation is mainly confined to the states of Karnataka (53.8\%), Kerala (18.9\%), Tamil Nadu (7.8\%) and other parts of North Eastern India (1.8\%). The global coffee bean production is surplus against consumption accounting to 99.11 lakh tonnes/ year with 3.38 per cent share from India. The productivity of coffee in India is $765 \mathrm{~kg} / \mathrm{ha}$. In Tamil Nadu, coffee is mainly produced in the Nilgiris, Shevroy hills, 
Pulney hills and Anamalai hills in 13,436 ha. The average production of Tamil Nadu is 17,440 tonnes/year and productivity of $519 \mathrm{~kg} / \mathrm{ha}$ (CCRI, 2018).

Despite the surplus production, insects are a major constraint in achieving higher yields. More than 100 insects have been recorded as pests in coffee (Le Pelley, 1968). Of these insect pests, coffee white stem borer (CWSB) Xylotrechus quadripes (Chevrolat, 1863) (Cerambycidae: Coleoptera) was observed to devastate the coffee bushes, sometimes, accounting to a crop loss of \$26-40 million (Hall et al., 2006; Venkatasha, 2010) elsewhere. The annual economic loss in India due to CWSB accounts to 0.64 million US dollars in 1987 and 1997 (Radhakrishnan et al., 1987; Naidu, 1997), 40 million US dollars in 2006 (Hall et al., 2006) and 26 million in 2010 (Venkatesha, 2010).

CWSB is considered to be a native of South East Asia had been recorded from China (Kuang et al., 1977), Sri Lanka, Thailand, Vietnam, Java and Burma (Le Pelley, 1968) and India (Stokes, 1838). In India, it is distributed over the arabica coffee tracts of Karnataka, Tamil Nadu, Kerala and Andhra Pradesh. The coffee productivity deficit of $246 \mathrm{~kg}$ in Tamil Nadu is mainly attributed to loss by insect damage. In the study area, Pulney hills, arabica coffee is widely grown in 13,436ha, where in CWSB is a recent menace. The adult emergence of the CWSB occurs during pre-monsoon period (April to May) post-monsoon period (October to November). The present study was undertaken to evaluate the bio-efficacy of bioagents viz., Beauveria bassiana, Bacillus subtilis and azadirachtin against CWSB in comparison with chemical insecticides so as to develop alternative methods of management, keeping in view of the health and environmental hazards by pesticide usage.

\section{Materials and Methods}

Two field experiments for the damage assessment based management of CWSB (Trial I and Trial II) were conducted from January, 2018 to January, 2019 at Kodai Nursery Estate, Thadiyankudisai, Dindigul, Tamil Nadu, $\left(77.71^{\circ} \mathrm{E}, 10.29^{\circ} \mathrm{N}\right)$ India. The efficacy of bio-agents Beauveria bassiana, Bacillus subtilis, azadirachtin and chemical insecticides viz., chlorpyriphos, chlorantraniliprole and fipronil $40 \%+$ imidacloprid $40 \% \mathrm{WG}$ were evaluated at the dosages presented in Table 1. The experiments were laid out in randomized block design and replicated three times. Each replication comprised 20 year old arabica coffee plants 10 in numbers. The treatments were imposed three times: I spray (first week of April, 2018), II spray (first week of October, 2018) and III spray (last week of October, 2018) coinciding with the adult emergence.

CWSB larvae damaged the coffee stem by making galleries that appeared like ridges made in a circular manner around the main stem and primary branches. Subsequently, the larvae tunneled into the stem feeding from within. Sometimes they bored down to the root resulting in yellowing of leaves and wilting of the plants.

The damage by CWSB was recorded by observing the ridge formation on the main stem and thick primary branches (Fig. 1).

The pre-treatment spray count on damage by CWSB was recorded one day before spray and the post treatment count was recorded on $10,20,30,40,50$ and 60 days after spray (DAS) for the I and III spray only, the post treatment count was limited to 10 and 20 DAS for the second spray so as to impose the II round of treatment during the first week of October, 2018. 
The coffee yield in different treatments was quantified separately in terms of $\mathrm{kg}$ per 30 plants.

The data recorded were transformed in to arc sin values for statistical scrutiny, the following method, WASP-Web Agri Stat Package

(http://www.ccari.res.in/wasp/rbd2.php).

\section{Results and Discussion}

\section{Field experiment of chemical and bio-agent against CWSB}

\section{Effect of bio-agents against CWSB in the I trial}

The results on efficacy of different chemicals and bio-agents revealed that there was significant difference between treatments in all three applications on the infestation level of the CWSB (Table 2). After first application the minimum infestation was recorded in chlorpyriphos $20 \mathrm{EC}+$ azadirachtin $1 \% \mathrm{EC} \&$ chlorpyriphos $20 \mathrm{EC}(40.56 \%)$ followed by Beauveria bassiana 2\% A.S. (41.11\%) sprayed plots and were on par with each other statistically. In the untreated control plots the infestation was maximum (52.22\%). Similar trend was noticed in second and third application also. However, during second and third treatment application the level of infestation was more. During third treatment spraying the untreated plots had maximum damage of 84.44 per cent by CWSB.

The infestation level was minimum in chlorpyriphos $20 \mathrm{EC}+$ azadirachtin $1 \% \mathrm{EC} \&$ chlorpyriphos 20 EC (45.56\%) applied plots. There was significant impact for the bio-agent Beauveria bassiana 2\% A.S and Bacillus subtilis $1.5 \%$ WS on the damage by CWSB. The level of infestation after third application in these treatments was 48.89 and 55.56 per cent respectively.
The field studies on the efficacy of bioagents against CWSB in the II trial

Among the three applications in all the treatments, the influence of synthetic insecticide sprays on CWSB damage has been realized (Table 3). The minimum damaged control ranged from 34.22 per cent (chlorpyriphos $20 \mathrm{EC}+$ azadirachtin $1 \% \mathrm{EC}$ ) and 34.91 per cent (chlorpyriphos 20 EC) followed by 35.59 per cent (Beauveria bassiana $2 \%$ A.S) and was significantly equal in treatment plots after the first application. The maximum incidence of CWSB was 51.11 per cent in untreated control plots. In these treatments, the second application also observed the same percentage of infestation, the maximum infestation was observed in untreated control plots $(61.67 \%)$ in second application.

The minimum per cent infestation (38-33) was observed in plots treated with insecticides (chlorpyriphos $20 \mathrm{EC}+$ azadirachtin 1\% EC and chlorpyriphos 20 EC) and were significantly on par with each other, followed by the bio-agent of Beauveria bassiana 2\% A.S. with 43.33 per cent in third application. In all the three application the maximum stem borer damage was observed in untreated control plots $80.56 \%$.

\section{Effect of bio-agents against CWSB on yield of coffee}

Coffee yield varied with treatments (Table 4). The coffee grown in the control plots (untreated) had the lowest yield compared to chemical treatments $(22.68$ and $22.40 \mathrm{~kg} / 30$ plants), respectively in the trial I and II. The insecticide treated plots with chlorpyriphos 20 $\mathrm{EC}+$ azadirachtin 1\% EC had the highest yield, (52.58 and $51.32 \mathrm{~kg} / 30$ plants), followed by chlorpyriphos 20EC (51.86 and $50.86 \mathrm{~kg} / 30$ plants) and Beauveria bassiana $2 \%$ A.S. (47.47 and $46.94 \mathrm{~kg} / \mathrm{plants}$ ). 
Table.1 Experiment treatments for the management of CWSB

\begin{tabular}{|c|c|c|c|c|c|}
\hline Treatments & $\begin{array}{c}\text { Quantity/litre } \\
\text { of water }\end{array}$ & $\begin{array}{l}\text { Types of } \\
\text { sprayer }\end{array}$ & $\begin{array}{l}\text { Types of } \\
\text { Nozzle }\end{array}$ & $\begin{array}{l}\text { Application } \\
\text { methods }\end{array}$ & $\begin{array}{c}\text { Formulated product } \\
\text { manufacturer }\end{array}$ \\
\hline $\begin{array}{l}\mathrm{T}_{1} \text { - Fipronil } 40 \% \text { + Imidacloprid } \\
40 \% \text { WG }\end{array}$ & $0.5 \mathrm{~g}$ & \multirow{10}{*}{$\begin{array}{c}\text { Knapsack } \\
\text { (15lit } \\
\text { capacity) }\end{array}$} & \multirow{10}{*}{$\begin{array}{l}\text { Hollow cone } \\
\text { nozzle (1000 } \\
\text { litre of spray } \\
\text { fluid per } \\
\text { hectare) }\end{array}$} & \multirow[t]{10}{*}{ Spraying } & $\begin{array}{l}\text { Bayer Crop Science } \\
\text { Limited, India }\end{array}$ \\
\hline $\mathbf{T}_{2}$ - Chlorantraniliprole $20 \mathrm{SC}$ & $0.5 \mathrm{ml}$ & & & & $\begin{array}{l}\text { DuPont India Private } \\
\text { Limited }\end{array}$ \\
\hline $\mathrm{T}_{3}$ - Chlorpyrifos $20 \mathrm{EC}$ & $3 \mathrm{ml}$ & & & & $\begin{array}{l}\text { Dow Agro Sciences India } \\
\text { Pvt. Ltd. }\end{array}$ \\
\hline $\mathrm{T}_{4}$ - Azadirachtin $1 \% \mathrm{EC}$ & $1 \mathrm{ml}$ & & & & E.I.D. Parry (India) Limited \\
\hline $\begin{array}{c}\mathrm{T}_{5} \text { - (Fipronil } 40 \%+\text { Imidacloprid } \\
\text { 40\%WG) + Azadirachtin 1\% EC }\end{array}$ & $0.5 \mathrm{~g}+1 \mathrm{ml}$ & & & & \multirow[t]{3}{*}{$\begin{array}{l}\text { Chemicals mixed before } \\
\text { spraying }\end{array}$} \\
\hline $\begin{array}{l}\mathrm{T}_{6} \text { - Chlorantraniliprole } 20 \mathrm{SC}+ \\
\text { Azadirachtin 1\% EC }\end{array}$ & $0.5 \mathrm{ml}+1 \mathrm{ml}$ & & & & \\
\hline $\begin{array}{l}\mathrm{T}_{7} \text { - Chlorpyrifos } 20 \mathrm{EC}+ \\
\text { Azadirachtin 1\% EC }\end{array}$ & $3 m l+1 m l$ & & & & \\
\hline $\mathrm{T}_{8}-$ Bacillus subtilis $1.5 \% \mathrm{WS}$ & $10 \mathrm{ml}$ & & & & TNAU Culture \\
\hline T9- Beauveria bassiana $2 \%$ A.S. & $10 \mathrm{ml}$ & & & & $\begin{array}{l}\text { International Panaacea } \\
\text { Limited, India }\end{array}$ \\
\hline $\mathbf{T}_{10}$ - Untreated control & - & & & & - \\
\hline
\end{tabular}


Table.2 Field evaluation of bio-agents against coffee white stem borer (Trial I)

\begin{tabular}{|c|c|c|c|c|c|}
\hline \multirow[t]{2}{*}{ Treatments } & \multirow{2}{*}{$\begin{array}{l}\text { Dose/lit of } \\
\text { water }\end{array}$} & \multirow[t]{2}{*}{ PTC } & \multicolumn{3}{|c|}{ Percent infestation after } \\
\hline & & & $1^{\text {st }}$ Application & $2^{\text {nd }}$ Application & $3^{\text {rd }}$ Application \\
\hline $\begin{array}{l}T_{1} \text { - Fipronil } 40 \% \text { + Imidacloprid } \\
40 \% \text { WG }\end{array}$ & $0.5 \mathrm{~g}$ & 36.67 & $\begin{array}{c}46.11 \\
(42.75) \mathrm{d}\end{array}$ & $\begin{array}{c}58.33 \\
(49.80) \text { ef }\end{array}$ & $\begin{array}{l}65.56 \\
(54.11) f\end{array}$ \\
\hline $\mathrm{T}_{2}$ - Chlorantraniliprole $20 \mathrm{SC}$ & $0.5 \mathrm{ml}$ & 40.00 & $\begin{array}{c}42.78 \\
(40.84) \mathrm{abc}\end{array}$ & $\begin{array}{c}50.00 \\
(45.00) \mathrm{bcd}\end{array}$ & $\begin{array}{c}55.00 \\
(47.87) \mathrm{cd}\end{array}$ \\
\hline $\mathrm{T}_{3}-$ Chlorpyrifos $20 \mathrm{EC}$ & $3 \mathrm{ml}$ & 40.00 & $\begin{array}{c}40.56 \\
(39.55) \mathrm{a}\end{array}$ & $\begin{array}{c}43.33 \\
(41.16) \mathrm{a}\end{array}$ & $\begin{array}{c}45.56 \\
(42.44) \mathrm{a}\end{array}$ \\
\hline $\mathrm{T}_{4}$ - Azadirachtin 1\% EC & $1 \mathrm{ml}$ & 36.67 & $\begin{array}{c}44.44 \\
(41.79) \mathrm{cd}\end{array}$ & $\begin{array}{c}53.33 \\
(46.91) \mathrm{cd}\end{array}$ & $\begin{array}{c}60.56 \\
(51.11) \mathrm{d}\end{array}$ \\
\hline $\begin{array}{c}\mathrm{T}_{5}-\text { (Fipronil } 40 \%+\text { Imidacloprid } \\
40 \% \mathrm{WG} \text { ) + Azadirachtin 1\% EC }\end{array}$ & $0.5 \mathrm{~g}+1 \mathrm{ml}$ & 40.00 & $\begin{array}{c}45.00 \\
(42.12) \mathrm{cd}\end{array}$ & $\begin{array}{c}55.00 \\
(47.88) \mathrm{cd}\end{array}$ & $\begin{array}{c}63.33 \\
(52.75) \mathrm{ef}\end{array}$ \\
\hline $\begin{array}{l}\mathrm{T}_{6} \text { - Chlorantraniliprole } 20 \mathrm{SC}+ \\
\text { Azadirachtin } 1 \% \text { EC }\end{array}$ & $0.5 \mathrm{ml}+1 \mathrm{ml}$ & 40.00 & $\begin{array}{c}41.67 \\
(40.17) \mathrm{ab}\end{array}$ & $\begin{array}{c}46.67 \\
(43.08) \mathrm{abc}\end{array}$ & $\begin{array}{c}51.67 \\
(45.95) \mathrm{bc}\end{array}$ \\
\hline $\begin{array}{l}\text { T }_{7} \text { - Chlorpyrifos } 20 \mathrm{EC}+ \\
\text { Azadirachtin 1\% EC }\end{array}$ & $3 \mathrm{ml}+1 \mathrm{ml}$ & 40.00 & $\begin{array}{c}40.56 \\
(39.55) \mathrm{a}\end{array}$ & $\begin{array}{c}43.33 \\
(41.16) \mathrm{a}\end{array}$ & $\begin{array}{c}45.56 \\
(41.02) \mathrm{a}\end{array}$ \\
\hline $\mathrm{T}_{8}-$ Bacillus subtilis $1.5 \% \mathrm{WS}$ & $10 \mathrm{ml}$ & 36.67 & $\begin{array}{c}43.33 \\
(41.15) \mathrm{bc}\end{array}$ & $\begin{array}{c}51.67 \\
(45.95) \mathrm{cd}\end{array}$ & $\begin{array}{c}55.56 \\
(48.19) \mathrm{d}\end{array}$ \\
\hline T $_{9}$ - Beauveria bassiana 2\% A.S. & $10 \mathrm{ml}$ & 40.00 & $\begin{array}{c}41.11 \\
(39.87) \mathrm{ab}\end{array}$ & $\begin{array}{c}45.00 \\
(42.12) \mathrm{ab}\end{array}$ & $\begin{array}{c}48.89 \\
(44.36) \mathrm{ab}\end{array}$ \\
\hline $\mathbf{T}_{10}$ - Untreated control & - & 43.33 & $\begin{array}{c}52.22 \\
(46.27) \mathrm{e}\end{array}$ & $\begin{array}{c}63.33 \\
(52.75) \mathrm{f}\end{array}$ & $\begin{array}{c}84.44 \\
(67.35) \mathrm{g}\end{array}$ \\
\hline CV \% & & 26.39 & 2.99 & 2.89 & 3.65 \\
\hline CD $(0.05 \%)$ & & NS & 1.44 & 2.98 & 2.10 \\
\hline SEm \pm & & 8.47 & 1.53 & 1.73 & 3.27 \\
\hline
\end{tabular}

PTC - Pre Treatment Count

Figures in parentheses are arc sin transformed values 
Table.3 Field evaluation of bio-agents against coffee white stem borer (Trial II)

\begin{tabular}{|c|c|c|c|c|c|}
\hline \multirow[t]{2}{*}{ Treatments } & \multirow{2}{*}{$\begin{array}{l}\text { Dose/litre } \\
\text { of water }\end{array}$} & \multirow[t]{2}{*}{ PTC } & \multicolumn{3}{|c|}{ Percent infestation after } \\
\hline & & & $1^{\text {st }}$ Application & $2^{\text {nd }}$ Application & $3^{\text {rd }}$ Application \\
\hline $\begin{array}{l}\mathrm{T}_{1} \text { - Fipronil } 40 \%+\text { Imidacloprid } \\
40 \% \mathrm{WG}\end{array}$ & $0.5 \mathrm{~g}$ & 36.67 & $\begin{array}{c}47.22 \\
(43.40) \mathrm{e}\end{array}$ & $\begin{array}{c}53.33 \\
(43.10) \mathrm{ef}\end{array}$ & $\begin{array}{c}55.00 \\
(47.87) \mathrm{e}\end{array}$ \\
\hline $\mathbf{T}_{2}$ - Chlorantraniliprole $20 \mathrm{SC}$ & $0.5 \mathrm{ml}$ & 40.00 & $\begin{array}{c}42.78 \\
(40.84) c\end{array}$ & $\begin{array}{c}46.67 \\
(45.00) c\end{array}$ & $\begin{array}{c}50.56 \\
(45.31) \mathrm{ed}\end{array}$ \\
\hline $\mathrm{T}_{3}$ - Chlorpyrifos $20 \mathrm{EC}$ & $3 \mathrm{ml}$ & 30.00 & $\begin{array}{c}34.91 \\
(32.78) \mathrm{a}\end{array}$ & $\begin{array}{c}36.67 \\
(39.23) \mathrm{a}\end{array}$ & $\begin{array}{c}38.33 \\
(37.26) \mathrm{a}\end{array}$ \\
\hline $\mathrm{T}_{4}$ - Azadirachtin 1\% EC & $1 \mathrm{ml}$ & 40.00 & $\begin{array}{c}44.44 \\
(41.80) \text { cde }\end{array}$ & $\begin{array}{c}51.67 \\
(43.10) \mathrm{ed}\end{array}$ & $\begin{array}{c}54.44 \\
(47.55) \mathrm{de}\end{array}$ \\
\hline $\begin{array}{c}\mathrm{T}_{5} \text { - (Fipronil 40\% + Imidacloprid } \\
40 \% \text { WG) + Azadirachtin 1\% EC }\end{array}$ & $0.5 \mathrm{~g}+1 \mathrm{ml}$ & 36.67 & $\begin{array}{c}46.67 \\
\text { (43.07)de }\end{array}$ & $\begin{array}{c}55.00 \\
(45.96) \mathrm{f}\end{array}$ & $\begin{array}{c}60.00 \\
(50.78) \mathrm{f}\end{array}$ \\
\hline $\begin{array}{l}\text { T}_{6} \text { - Chlorantraniliprole } 20 \mathrm{SC} \\
\text { + Azadirachtin 1\% EC }\end{array}$ & $0.5 \mathrm{ml}+1 \mathrm{ml}$ & 36.67 & $\begin{array}{c}37.92 \\
(37.78) b\end{array}$ & $\begin{array}{c}40.00 \\
(42.12) b\end{array}$ & $\begin{array}{c}46.11 \\
(42.75) \mathrm{c}\end{array}$ \\
\hline $\begin{array}{l}\mathrm{T}_{7} \text { - Chlorpyrifos } 20 \mathrm{EC}+ \\
\text { Azadirachtin 1\% EC }\end{array}$ & $3 \mathrm{ml}+1 \mathrm{ml}$ & 30.00 & $\begin{array}{c}34.22 \\
(31.67) \mathrm{a}\end{array}$ & $\begin{array}{c}36.67 \\
(37.27) \mathrm{a}\end{array}$ & $\begin{array}{c}38.33 \\
(37.26) \mathrm{a}\end{array}$ \\
\hline $\mathrm{T}_{8}-$ Bacillus subtilis $1.5 \%$ WS & $10 \mathrm{ml}$ & 36.67 & $\begin{array}{c}43.33 \\
(41.15) \mathrm{cd}\end{array}$ & $\begin{array}{c}50.00 \\
(41.16) \mathrm{d}\end{array}$ & $\begin{array}{c}51.67 \\
(45.95) \mathrm{cd}\end{array}$ \\
\hline T9 $_{9}$ Beauveria bassiana $2 \%$ A.S. & $10 \mathrm{ml}$ & 33.33 & $\begin{array}{c}35.59 \\
(33.89) \mathrm{a}\end{array}$ & $\begin{array}{c}38.33 \\
(39.23) \mathrm{ab}\end{array}$ & $\begin{array}{c}43.33 \\
(41.16) b\end{array}$ \\
\hline $\mathbf{T}_{10}$ - Untreated control & - & 33.33 & $\begin{array}{c}51.11 \\
(45.63) \mathrm{f}\end{array}$ & $\begin{array}{c}61.67 \\
(51.75) \mathrm{g}\end{array}$ & $\begin{array}{c}80.56 \\
(64.22) \mathrm{g}\end{array}$ \\
\hline $\mathrm{CV} \%$ & & 22.85 & 7.06 & 2.60 & 3.92 \\
\hline CD $(0.05 \%)$ & & NS & 3.38 & 2.75 & 2.10 \\
\hline SEm \pm & & 6.60 & 8.64 & 1.48 & 3.26 \\
\hline
\end{tabular}

PTC -Pre Treatment Count

Figures in parentheses are arc sin transformed values 
Table.4 Effect of CWSB on yield of coffee (Trial I \& II)

\begin{tabular}{|c|c|c|c|}
\hline \multirow[t]{2}{*}{ Treatments } & \multirow{2}{*}{$\begin{array}{l}\text { Dose/litre of } \\
\text { water }\end{array}$} & \multicolumn{2}{|c|}{ Yield (Kg/30plants) } \\
\hline & & Trial I & Trial II \\
\hline $\mathrm{T}_{1}$ - Fipronil $40 \%$ + Imidacloprid $40 \% \mathrm{WG}$ & $0.5 \mathrm{~g}$ & $28.68 \mathrm{f}$ & $27.85 \mathrm{~g}$ \\
\hline $\mathbf{T}_{2}$ - Chlorantraniliprole $20 \mathrm{SC}$ & $0.5 \mathrm{ml}$ & $37.23 \mathrm{~cd}$ & $40.38 \mathrm{~d}$ \\
\hline $\mathrm{T}_{3}$ - Chlorpyrifos $20 \mathrm{EC}$ & $3 \mathrm{ml}$ & $51.86 \mathrm{a}$ & $50.86 a$ \\
\hline $\mathrm{T}_{4}$ - Azadirachtin 1\% EC & $1 \mathrm{ml}$ & 33.56de & $32.79 f$ \\
\hline $\begin{array}{l}\mathrm{T}_{5}-(\text { Fipronil } 40 \%+\text { Imidacloprid } 40 \% \mathrm{WG})+ \\
\text { Azadirachtin } 1 \% \text { EC }\end{array}$ & $0.5 \mathrm{~g}+1 \mathrm{ml}$ & $30.32 \mathrm{ef}$ & $29.64 \mathrm{~g}$ \\
\hline $\begin{array}{l}\mathrm{T}_{6} \text { - Chlorantraniliprole } 20 \mathrm{SC}+\text { Azadirachtin } \\
1 \% \mathrm{EC}\end{array}$ & $0.5 \mathrm{ml}+1 \mathrm{ml}$ & $41.25 c$ & $44.06 \mathrm{c}$ \\
\hline $\mathrm{T}_{7}-$ Chlorpyrifos $20 \mathrm{EC}+$ Azadirachtin 1\% EC & $3 \mathrm{ml}+1 \mathrm{ml}$ & $52.58 \mathrm{a}$ & $51.32 \mathrm{a}$ \\
\hline $\mathrm{T}_{8}-$ Bacillus subtilis $1.5 \%$ WS & $10 \mathrm{ml}$ & $37.11 \mathrm{~cd}$ & $36.74 \mathrm{e}$ \\
\hline T9- Beauveria bassiana $2 \%$ A.S. & $10 \mathrm{ml}$ & $47.17 b$ & $46.94 b$ \\
\hline $\mathbf{T}_{10}$ - Untreated control & - & $22.68 \mathrm{~g}$ & $22.40 \mathrm{~h}$ \\
\hline $\mathrm{CV} \%$ & & 6.70 & 4.31 \\
\hline CD $(0.05 \%)$ & & 4.40 & 2.83 \\
\hline SEm \pm & & 6.56 & 2.73 \\
\hline
\end{tabular}


Fig.1 Nature of damage due to Coffee White Stem Borer

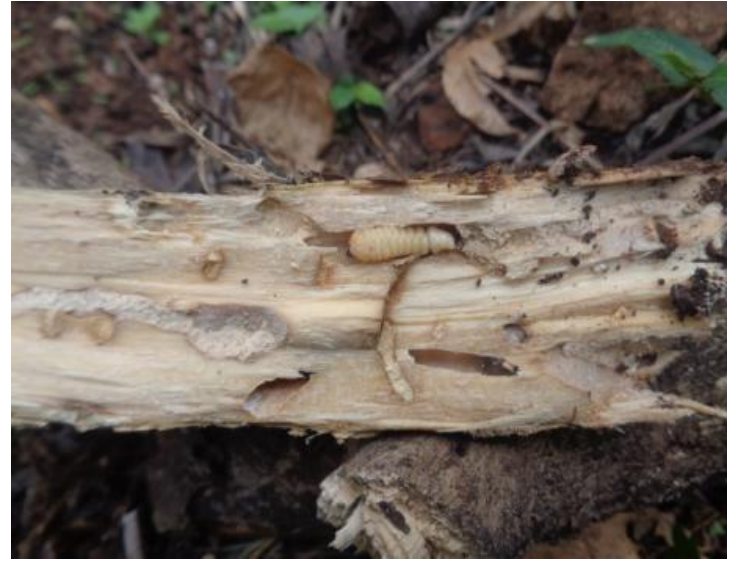

a. Infested stem showing borer tunnels with grub

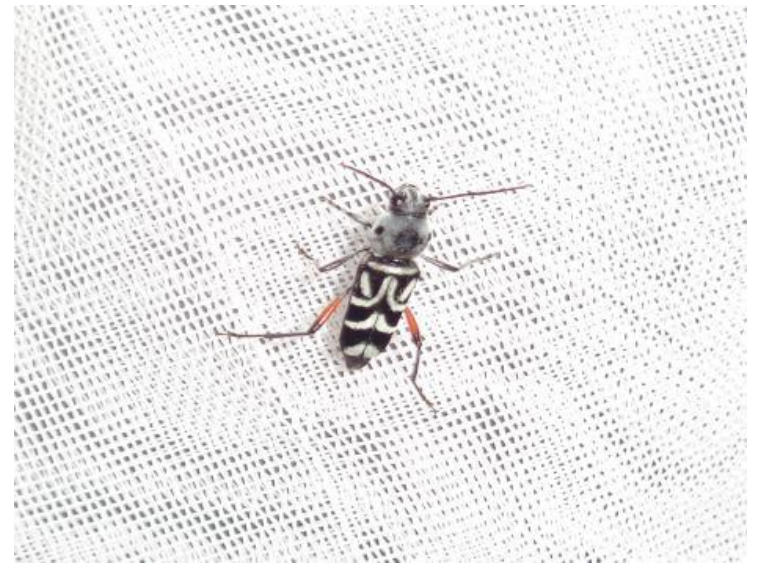

c. CWSB Adult

In both field trial the lower yield was recorded in fipronil $40 \%$ + imidacloprid $40 \%$ WG (28.68 and $27.85 \mathrm{~kg} / 30$ plants) over the untreated control.

\section{Management of coffee white stem borer}

In vitro laboratory studies conducted by Seetharama et al., (2004) showed that chlorpyriphos was more effective against eggs, while carbosulfan was more effective against larvae of the fifth instar, and both chlorpyriphos and carbosulfan were effective against adults. chlorpyriphos is more effective and less hazardous than lindane and is recommended for application on the stem during the peak periods of CWSB emergence (Vinod Kumar et al., 2009). Venkatesha and

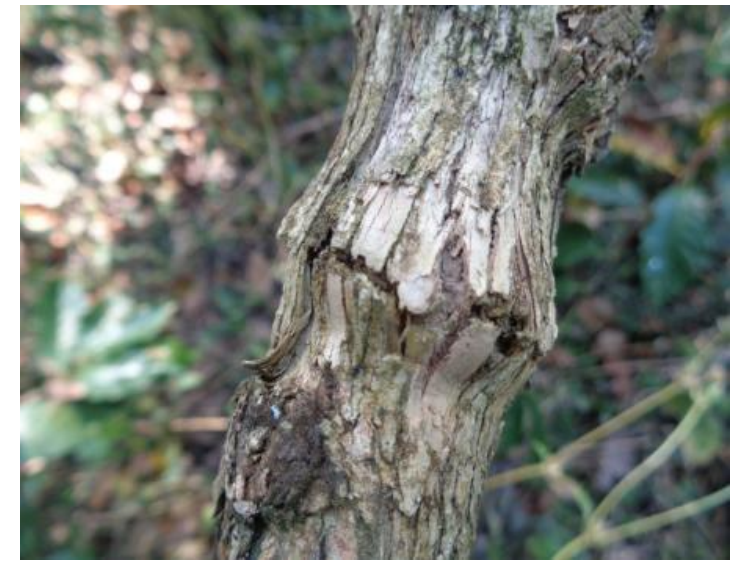

b. Ridges formation due to CWSB

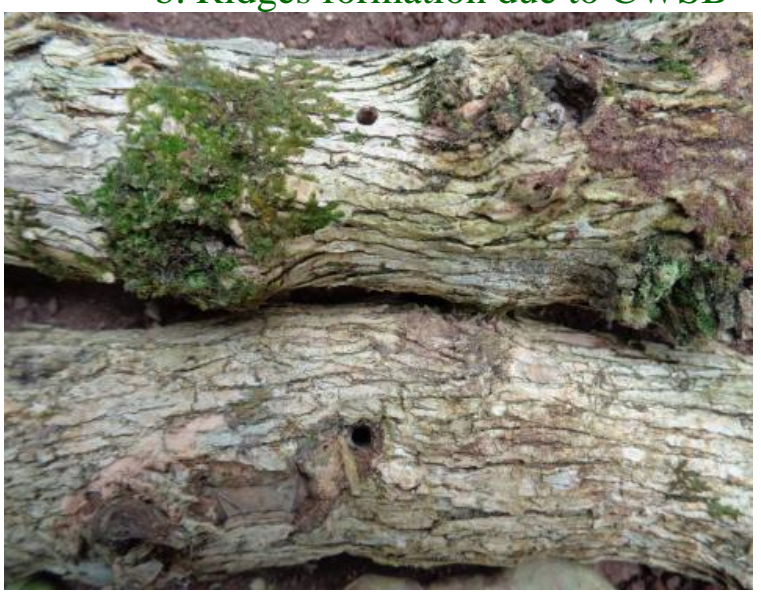

d. Boreholes of CWSB on coffee stem

Seetharama (1999) reported that organic insecticides such as chlorpyriphos killed the CWSB's first instar larvae in laboratory conditions for 77-83 days.

CCRI (2017) reported that chlorpyriphos 50 EC and chlorantraniliprole 18.5 SC caused 70.51 per cent mortality of neonate grub of CWSB under laboratory conditions. Our field evaluation of (chlorpyriphos 20 EC + azadirachtin $1 \%$ EC), chlorpyriphos 20 EC and chlorantraniliprole $20 \mathrm{SC}$ resulted significant management of CWSB infestations from $45.56 \%$ and $55.00 \%$ (Trial I), in Trial II from $38.33 \%$ and $50.56 \%$ respectively. CCRI (2018) recommends the use of non-woven fabric material with a thickness of 0.4 or $1.3 \mathrm{~mm}$ for wrapping the 
stem of infested plants and spraying with a combination of insecticide (chloripyriphos 50EC + cypermethrin 5EC) @ $1.2 \mathrm{ml}$ per litre, together with $1 \mathrm{ml}$ of any wetting agent, which reduces the infestation by 74-100 percent of adult beetle mortality at the emergency site per exit hole under field conditions.

Venkatesha (1999) reported that for effective control of the pest, management methods are to be improved. Since, the control of CWSB by synthetic insecticides possesses risks due to the coincidence of the flight periods with pre and post-monsoon rains which results in washing of insecticides. In addition, largescale applications of insecticides kill natural enemies of CWSB and other pests (Venkatesha, 2005).

The strain of $B$. bassiana utilized in our study is IPL/BB/MI-01 with a CFU count of $2 \times 10^{8}$ per $\mathrm{ml}$ which resulted in a mortality range between $48.89 \%$ (Trial I) and $43.33 \%$ (Trial II) under field condition. This is comparable with the study of Aristizabal et al., (1997) where B. bassiana strain 'GHA' was used to manage coffee berry borers resulting in 28 per cent mortality (CBB) in field condition in Hawaii and Wei and Kuang (2000) observed that $B$. bassiana caused 90 per cent mortality of $X$. quardripes within 15 days under laboratory conditions in China. In India, CCRI (2017) studied B. bassiana under laboratory conditions to manage $\mathrm{CBB}$ which resulted in 100 per cent mortality within six days after inoculation and field trials were proposed to evaluate its efficacy. This mortality data depicts the necessity to integrate $B$. bassiana in IPM packages to manage coleopteran pests in coffee ecosystem.

Yield loss from plants infested with coffee white stem borer in Nepal was comparable to that in India and some African countries. In
Tanzania, moderately infested coffee plants produced as much as $65 \%$ less than noninfested plants (Magina, 2005). Oduor and Simons (1999) reported cumulative yield loss of as much as $77 \%$ on coffee farms managed by smallholders in northern Malawi, and Murphy et al., (2008) reported 25\% in Zimbabwe.

A study in 90 randomly selected coffee plantations in India showed $45 \%$ of plants infested by coffee white stem borer and mean annual yield loss of 35\% (Joy, 2004). Indian farmers annually removed more than 9 million coffee plants that cost approximately $\$ 40$ million to replace and in yield loss (Hall et al., 2006).

\section{Acknowledgement}

The financial assistance for research from the School of Post Graduate Studies, Tamil Nadu Agricultural University, Coimbatore is gratefully acknowledged. The authors sincerely thank the staff, students and supporting staff for Agricultural College and Research Institute (AC \& RI), Madurai, Department of Agricultural Entomology, Tamil Nadu Agricultural University, Coimbatore, Horticultural Research Station, Thadiyankudisai and Regional Coffee Research Station, Thandikudi for the kind help rendered during the study.

\section{References}

Aristizabal, A.L.F., Baker, P.S., Orozco H.J and Chaves. C.B. 1997. Parasitism of Cephalonomia stephanoderis Betrem on population of Hypothenemus hampei Ferrari at infestation low levels in the field. Revista Colomibiana de Entomologia, 23 (3-4): 157-164.

CCRI, 1998. A compendium on pests and diseases of coffee and their management in India. Central Coffee 
Research Institute, Chikmagalur. 4 pp. CCRI, 2003. Coffee Guide. Central Coffee Research Institute, Coffee Research Station, Chikmagalur.

CCRI, 2017. Seventeenth Annual Report, Central Coffee Research Institute, Coffee Research Station, Chikmagalur.

CCRI, 2018. Database on coffee, Market Research \& Intelligence Unit, Central Coffee Research Institute, Coffee Research Station, Chikmagalur.

CCRI, 2018. Indian Coffee, Central Coffee Research Institute, Coffee Research Station, Chikmagalur.p22.

Hall, D.R., Cork, A., Phythian, S.J., Chittamuru, S., Jayarama, B.K., Venkatesha, M.G., Sreedharan, K., Kumar, P.K.V., Seetharama, H.G and Naidu, R. 2006. Identification of components of male-produced pheromone of coffee white stem borer, Xylotrechus quadripes. Journal of Chemical Ecology. 32, 195-219.

http://www.ccari.res.in/wasp/rbd2.php

Joy, C.V. 2004. Small coffee growers of Sulthan Bathery and Wayanad. Kerala research programme on local level development, Centre for Development Studies, India.

Kung, P.C. 1977. Studies on two long-horned beetles infesting coffee trees in Kwangsi Autonomous Region. Acta Entomologica Sinica. 20, 49-56.

Le Pelley, R.H. 1968. Pests of Coffee. Longmans, Green and Co. Ltd, London. pp.590.

Magina, F.L. 2005. A Review of Coffee Pest Management. Tanzania Coffee Research Institute, Tanzania.

Murphy, T.S., Phiri, N.A., Sreedharan, K., Kutywayo, D and Chanika. C. 2008. Integrated Stem Borer Management in Smallholder Coffee Farms in India, Malawi and Zimbabwe. Final Technical Report. CABI, UK.

Naidu, R. 1997 White stem borer in coffee, current management and future strategies. Planters Chronicle 92, 519522.

Oduor, G.I., and Simons. S.A. 1999. Integrated pest management of coffee pests on smallholder farms in Malawi. Final Technical Report. CABI, UK.

Radhakrishnan, S., Ramaiah P.K. and Bhat P.K. 1987. Methodology to estimate yield loss in coffee due to insect pests. Journal of Coffee Research, 17, 90-93.

Seetharama, H.G., Vasudev V., Kumar P.K.V. and Sreedharan K. 2004. Studies on the biology of coffee stem borer - a method to facilitate oviposition in the laboratory. Journal of Coffee Research, 32, 111-116.

Sekhar, P.S. 1958. Pests of coffee and their control. Indian Coffee. 22, 220-243.

Stokes. H. 1838. Report of the Commissioner, Mysore, 1838.

Subramaniam, T.V. 1934. The coffee stem borer. Entomological Series-Bulletin, Department of Agriculture (Mysore, India). 11, 1-18.

Venkatesha, M.G. 1999. Why is white stem borer persistently a serious pest in arabica coffee plantations? Indian Coffee: Bulletin of the Indian Coffee Board, 63, 11-14.

Venkatesha, M.G. 2005. Natural way of managing major insect pests of coffee, pp. 277-282. In Green Pesticides for Insect Pest Management (Edited by S. Ignasimuthu and S. Jayaraj). Narosa Publishing House, Chennai.

Venkatesha, M.G. 2010. Sustainable coffee cultivation in India: challenges and management, pp. 492-495.In Proceedings of the 16th Asian Agricultural Symposium and 1st International Symposium on Agricultural Technology, 19-21 November, Faculty of Agricultural Technology, King Mongkut's Institute of Technology Ladkrabang, Bangkok, 
Thailand.

Venkatesha, M.G. and Seetharama H.G. 1999.

Evaluation of some insecticides and natural products against coffee white stem borer, Xylotrechus quadripes Chevr. (Coleoptera: Cerambycidae). Entomon, 25, 331-333.

Vinod Kumar, P.K., Seetharama, H.G., Balakrishna, M.M., Irulandi, S. and
Jayarama. 2009. The coffee white stem borer - an insight. Indian Coffee, 73, 811.

Wei, J.N. and Kuang, R. P. 2000. Application of capture recapture models for estimating coffee stem borers (Coleoptera: Cerambycidae) abundance. Insect Science and its Application (1): 3943.

\section{How to cite this article:}

Manikandan, K.R., M. Muthuswami, N. Chitra and Ananthan, M. 2019. Management of Coffee White Stem Borer Xylotrechus quadripes (Chevrolat, 1863) (Coleoptera: Cerambycidae) in the Lower Pulney Hills, India. Int.J.Curr.Microbiol.App.Sci. 8(06): 1703-1713. doi: https://doi.org/10.20546/ijcmas.2019.806.203 